UDC 556.16

Valeriya Anatolievna Ovcharuk,

Doctor of Sciences (Geography), Associate Professor,

Director of the Hydrometeorological Institute of Odessa State Environmental University,

15 Lvivska Str., 65016, Odessa, Ukraine,

e-mail: valeriya.ovcharuk@gmail.com, https://orcid.org/0000-0003-1638-841X;

Oleg Miloslavovich Prokofiev,

$\mathrm{PhD}$ (Geography), Associate Professor,

Department of Meteorology and Climatology, Odessa State Environmental University, e-mail: leggg0707@gmail.com, https://orcid.org/0000-0002-5669-0181;

Olena Ivanivna Todorova,

$\mathrm{PhD}$ (Geography), Senior Lecturer,

Department of Land Hydrology, Odessa State Environmental University,

e-mail: lenochka.todorova1989@gmail.com, https://orcid.org/0000-0001-8937-7952;

Natalia Sergiyvna Kichuk,

$\mathrm{PhD}$ (Geography), Associate Professor,

Department of Land Hydrology, Odessa State Environmental University, e-mail: kichuknatali@ukr.net, https://orcid.org/0000-0002-8165-6743

\title{
THE STUDY OF THE PERIODICITY OF CATASTROPHIC SPRING FLOODS ON THE TERRITORY OF UKRAINE
}

В. А. Овчарук, О. М. Прокоф'єв, О. І. Тодорова, Н. С. Кічук. ДОСЛДЖЕННЯ ПОВТОРЮВАНОСТІ КАТАСТРОФІЧНИХ ВЕСНЯНИХ ВОДОПІЛЬ НА ТЕРИТОРЇ̈ УКРАЇНИ. В статті представлені результати аналізу історичних даних про визначні паводки і водопілля катастрофічного характеру, оцінено їх повторюваність в історичному контексті $i$ на сучасних даних. Показано, ще як за даними вітчизняних вчених, так й за результатами оцінок міжнародних організачій (Centre for Research on the Epidemiology of Disasters, World Meteorological Organization), для території Украӥни найбільша повторюваність небезпечних природних явищ (51,9\%) припадає на паводки різного походження. Проаналізовано найбільш тривалі часові ряди максимального стоку весняного водопілля на рівнинних річках Украйни, виконано опис катастрофічних, багатоводних і маловодних водопіль. Проведений аналіз підтвердив можливість віднесення водопілля 1932 та 1970 років до категорії катастрофічних за масштабом території, які вони охоплювали - так водопілля 1932 року відмічене в басейнах Дніпра, лівобережжя Дністра, Південного Бугу та Сіверського Діния, а 1970 року - практично за всією територією басейну Дніпра, а також на річках Приазов'я. В иіломуж найбільш багатоводними за тривалий період спостережень, як за загальним об'ємом весняного стоку, так і за максимальними витратами води водопілля в Україні формувалися у 1932, 1942, 1947, 1956, 1960, 1963, 1970, 1971, 1978, 1979, 1980, 1986, 1988, 1994 рр., а маловодні весни припадали на 1944, 1950, 1954, 1962, 1965, 1969, 1975, 1976, 2007, 2008, 2009, 2014, 2015 рр. Аналіз тенденцій у рядах річних максимумів в умовах змін клімату показав їх неоднорідність за територією Украӥни, а саме на лівобережжі Дніпра та в басейні Сіверського Діния спостерігається тенденція до більш ранніх дат сніготанення та проходження водопілля, в той час, коли на решті територіі навпаки - наявна тенденція до збільшення випадків зимових паводків замість весняних водопіль.

Ключові слова: повені, паводки, водопілля, максимальний стік, зміни клімату.

В. А. Овчарук, О. М. Прокофьев, Е. И. Тодорова, Н. С. КИчук. ИССЛЕДОВАНИЕ ПОВТОРЯЕМОСТИ КАТАСТРОФИЧЕСКИХ ВЕСЕННИХ ПОЛОВОДИЙ НА ТЕРРИТОРИИ УКРАИНЫ. В статье приведены результаты анализа исторических данных о выдающихся паводках и половодьях катастрофического характера, оценена их повторяемость в историческом контексте и на современных данных. Показано, что как по данным отечественных ученых, так и по результатам оценок международных организаций (Centre for Research on the Epidemiology of Disasters, World Meteorological Organization), для территории Украины наибольшая повторяемость опасных природных явлений (51,9\%) приходится на паводки различного происхождения. Проанализированы наиболее длительные временные ряды максимального стока весеннего половодья на равнинных реках Украины, выполнено описание катастрофических, многоводных и маловодных половодий. Выполненный анализ подтвердил возможность отнесения половодья 1932 и 1970 годов в категорию катастрофических по масштабу территории, которые они охватывали. В частности, половодья 1932 года отмечено в бассейнах Днепра, левобережье Днестра, Южного Буга и Северского Дониа, а в 1970 году - практически по всей территории Днепра, а также на реках Приазовья. В иелом же наиболее многоводными за длительный период наблюдений, как по общему объему весеннего стока, так и по максимальным расходам воды половодья в Украине формировались в 1932, 1942, 1947, 1956, 1960, 1963 , 1970, 1971, 1978, 1979, 1980, 1986, 1988, 1994, а маловодные весны приходились на 1944, 1950, 1954, 1962, 1965, 1969, 1975, 1976, 2007, 2008, 2009, 2014, 2015 рр. Анализ тенденций в рядах годовых максимумов в условиях изменений климата показал их неоднородность по территории Украины, а именно на левобережье Днепра и в бассейне Северского Дониа наблюдается тенденция к более ранним датам снеготаяния и прохождения половодья, в то время, когда на остальной территории наоборот - наблюдается тенденщия к увеличению случаев зимних паводков вместо весенних половодий.

Ключевые слова: наводнения, паводки, половодья, максимальный сток, изменения климата.

Introduction. In the period of global and regional climate changes in almost all the regions of our planet there is an increase in cases of extreme natural phenomena, which definitely include floods of different origin. In the last decades, according to the data of the Centre for Research on the Epidemi-

(C) Ovcharuk V. A., Prokofiev O. M., Todorova O. I., Kichuk N. S.

https://doi.org/10.26565/2410-7360-2019-50-10 
ology of Disasters (CRED) [1-4], in many countries of the world there is a record high number of natural disasters which affected about 2.7 billion people, that is more than a third of the world's population. Regarding floods, in most parts of the globe, they are caused by prolonged cloudburst and storms as a result of passing cyclones. On the rivers of the Northern Hemisphere, floods are caused by the rapid snowmelt, snow dam and ice jam. In areas with snow cover, which is about $1 / 3$ of the land surface, spring and rain floods are the most common. They are especially widespread in Eurasia and North America.

Flood is formed due to the main source of feeding (on plain rivers due to snowmelt, in high mountains due to melting of snow and glaciers, in monsoon and tropical zones as a result of spring and summer precipitation, etc.). For rivers in one climatic zone, it annually repeats in the same season with different intensity and duration. Snow melting at plain rivers catchments causes the emergence of spring floods, the melting of high mountain snow and glaciers, and also rain falls cause springsummer and summer floods [5-6]. Sharp and continuous increase in temperature in spring with significant stocks of water in the snow influences greatly the nature of formation and flow of the flood. Floods become catastrophic if the infiltration properties of soils have decreased significantly due to their moisture saturation as a result of abundant autumn rains and deep freezing in severe winters. Spring rains can cause a significant increase of floods, when the snowmelt flood peak coincides with the peak of the rain flood.

According to the size and scale of damage R.A. Nezhikhovsky [7] proposed the classification of floods and divided them into: low (small), high, significant and catastrophic. The catastrophic floods cause enormous material loss and lead to the people's deaths, covering enormous areas within one or more river systems; more than $70 \%$ of agricultural land, a large number of settlements, industrial plants and utilities are flooded; economic and production activities are completely paralyzes, the way of life of the population is temporally changed. Periodicity of this phenomenon is once in 100-200 years.

The aim of the study is to analyze historical data and study the current state and trends in the frequency of catastrophic spring floods in Ukraine.

Analysis of previous studies and publications. First of all historical data on patterns of formation of most famous catastrophic floods has been analyzed. Floods have been accompanying human society since ancient times, so far we have information about catastrophic floods in ancient China (on the Yellow River in 2297 BC) and Egypt (on the Nile River about 3 thousand years ago). At one time
E.P. Borisenkov and V.M. Pasechnik in the monograph «Extreme natural phenomena in the Russian chronicles of the XI-XVII centuries» [8], on the basis of the study of chronicles provided the assessment of climate of Holocene on both the European continent and the entire Northern Hemisphere. The study analyzed in detail extreme meteorological phenomena observed from 979 to 1700 years in the territory from the Vistula to the $\mathrm{Ob}$ and from the Black Sea to the shores of the Arctic Ocean. But the most interesting is the final part of the monograph, which summarizes data on extreme natural phenomena. Based on the data [8] on the high spring flood, and taking into consideration the current data the diagram of periodicity of this natural phenomenon in the period from 900 to 2010 on the territory of Kievan Rus' and modern Ukraine has been made up (Figure 1).

While making up the diagram, mostly data on major floods on the Dnieper has been taken into account - the largest floods took place in 1128, 1655, 1684, 1789, 1931, 1932 and 1970. The flood of 1931 was unsurpassed according to the height of water level and flood zone area which spread from Mogilev in the north to Zaporozhye in the south.

The resulting distribution is purely illustrative, but it still makes it possible to assess the overall pattern of catastrophic spring floods repetition. Analyzing their frequency, one can notice that most of them were observed during the periods from 1501 to 1600 (11 cases), from 1601 to 1700 (13 cases) and in the modern period - from 1901 to 2000 (10 cases); 9001000 and $1701-1800$ years - are the periods with the fewest number of cases.

Since the beginning of the new millennium, catastrophic and high floods have been observed in Europe almost every year. "Great Water" in 2002 was the reason for the media to talk about the new World Flood and once again reminded that, despite all the achievements of modern civilization, a human being is sometimes powerless in the face of the power of nature. In August 2002 during a few days large areas of the Czech Republic, Slovakia, Germany, Austria, France, Switzerland, Poland, Italy, Spain, Romania, Moldova, Hungary and Serbia were under water. Floods in 2002 took lives of 3,000 people, the dwellings of 17 million people from over 80 countries were ruined. According to the World Meteorological Organization, the territory with a total area of more than 8 million square kilometers was flooded [9]. The total damage inflicted by the disaster is estimated at $\$ 30$ billion. According to European experts, it was the largest flood of the century in Europe.

On the territory of Ukraine during the 20th and early 21 st centuries, floods of various origin were repeatedly observed, of which the following can be 


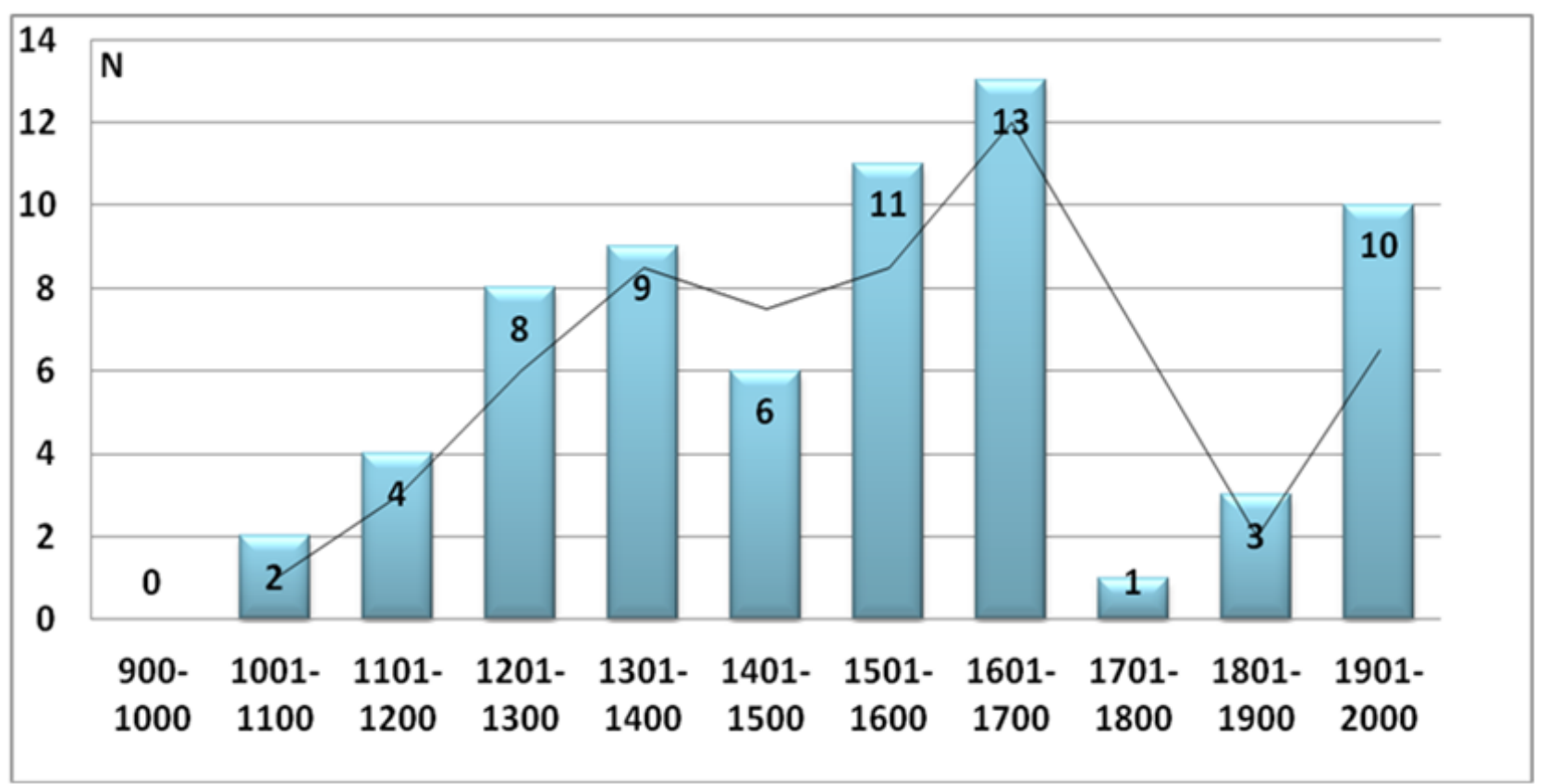

Fig. 1. Time distribution of outstanding spring floods on the territory of Kievan Rus and modern Ukraine: $\mathrm{N}$ - number of cases per period.

classified as catastrophic ones [10,11]:

1911 (July, $\left.8^{\text {th }}-9^{\text {th }}\right)$ - in the basins of the Dniester, Prut and Siret rivers floods were formed from storm rains, which were the largest ones over the entire period of available observations on the area of the river Prut below the influx of the Cheremosh River and in the foothills of the Siret River.

1927 (August, 30 ${ }^{\text {th }}-31^{\text {st }}$ ) - flooding in the basins of the Dniester and Prut rivers led to flooding of 10 cities and numorous villages, destroyed roads, bridges and more.

1931 - an unusually high spring flood in the basin of the Dnieper River. Its level exceeded all previously known floods from the XVIII century; great damage to the population was caused.

1941 (September, $1^{\text {st }}-2^{\text {nd }}$ ) - an extreme flood in the Dniester River basin caused significant damage.

1947 (the end of December) - strong warming and intense rains led to the formation of a catastrophic flood in Transcarpathia. Floods have seriously damaged the population of villages and towns. More than 35 railway bridges were destroyed, protective dams in the cities Vilok, Hust, the railroad were eroded, fertile soils were washed away, winter crops were ruined. Mud-stream, landfalls and landslides were observed.

1957 (June, $12^{\text {th }}-13^{\text {th }}$ ) - in the Carpathian region a catastrophic rainstorm caused the formation of a flood, which resulted in a huge material loss: the railroad was washed out, villages were flooded, farm buildings were demolished, agricultural crops were damaged and ruined on large areas.

1970 - a spring flood. A great rise in the water level and flooding of the territories were observed in the Dnipro river basin, including inflowing streams - the Desna and the Pripyat; population and economy of Kiev, Chernigov, Zhytomyr, Rivne and Sumy regions experienced substantial losses.

1980 (July) - a catastrophic flood was formed by significant precipitation in the basin of the Transcarpathian rivers, as well as the Dniester, Prut, and Siret; the national economy and the population in these areas were inflicted huge losses.

1998 (November, $3^{\text {rd }}-5^{\text {th }}$ ) - a catastrophic flood in Transcarpathia, which resulted in flooding more than 40 thousand buildings, about 2 thousand of which were completely destroyed. Waterproof dams, roads, bridges, railways were destroyed and damaged.

2001 (March, $\left.4^{\text {th }}-9^{\text {th }}\right)-$ a catastrophic flood in Transcarpathian region. For three days, there were two norms of monthly precipitation; water levels on some rivers exceeded the 1.5-2 m flood level of 1998. The flood caused tremendous destruction, 9 people died.

2008 (July, $\left.22^{\text {nd }}-27^{\text {th }}\right)-$ a catastrophic flood in six western regions of Ukraine, with 20 thousand dwellings, $2020 \mathrm{~km}$ of roads, 7 thousand hectares of agricultural lands flooded, hundreds of bridges were damaged, and about 30 people died.

Thus, according to the data of national scientists [5-7,10], and according to the results of international assessments CRED [1-4], for the territory of Ukraine, the greatest repetition of dangerous natural phenomena $(51,9 \%)$ falls on floods of different origin. In particular, according to the results of the 2008 flood, according to the CRED rankings, Ukraine took the ninth place in the world. 
R.A. Nezhikhovsky in the monograph [7] analyzed the distribution of water resources and floods with rare probability of relative height (from 1 to $5 \%$ ) in the territory of the former USSR. If we consider the plain territory of Ukraine, then there were highlighted the above-mentioned catastrophic floods of 1931 and 1932; in particular, the flood in 1931 is classified as maximum water discharge with probability of $\mathrm{P} \approx 1 \%$ and the flood in 1932 is classified as a year with probability of maximum water discharge $\mathrm{P} \approx 1-5 \%$.

Materials and methods. For the analysis of major floods, that have been observed in lowland rivers, the observational data of the State Hydrometeorological Service of Ukraine was used. Figures 29 show the chronological graphs of the maximum runoff of spring floods according to hydrological stations, which have the largest and in most cases continuous observation periods from their beginning until 2015 inclusive. To estimate the trends in the chronological series of the maximum runoff of rivers the methods of statistical analysis and spatial generalization have been used.

Results. While analyzing the presented diagrams, it should be noted that the floods of 1932 and 1970 can be classified as catastrophic according to the size of the territory it covered - so the flood of 1932 was observed in the basins of the Dnieper, the left bank of the Dniester, the Southern Bug and the Siverskyi Donets (Fig. 2-6), and in 1970 the flood was spotted basically throughout all the territory of the Dnieper (Fig. 2, 5), as well as on the rivers of the Azov Sea (Fig. 7).

In general, the most water-abundant over a long period of observation, both on total volume of the spring runoff and on maximum water discharges, spring floods were formed in Ukraine in 1932, 1942, 1947, 1956, 1960, 1963, 1970, 1971, 1978, 1979, 1980, 1986, 1988, 1994 years, and the dry spring floods were in 1944, 1950, 1954, 1962, 1965, 1969, 1975,1976 years [13-15]. On the other hand, in the Western Bug basin, the flood in 1970 was lower than normal and high floods occurred in 1952 and 1966 (Figure 8).

If we consider the upper Dniester, where the most water-abundant phase is the floods of warm period, but high spring floods are also possible, the most outstanding floods occurred here in the last 20 years - in 1998, 2000 and 2006 (Fig. 9).

In recent years $(2007,2008,2009,2014,2015)$ snow stocks basically didn't accumulate in a large part of the extreme south of Ukraine, that led to the lack of spring floods on the rivers or even their absence (Fig.3-4, 6-7). However, on the background of dry years of the past decades the most waterabundant floods were marked in 1998, 2003, 2006, and 2010. In some gauges in 2010 and 2013, according to the data of UHMC [15], the relative height of the maximum water levels was marked during the flood on the Danube and the Upper Dnieper.

According to research of European scientists, including a group of researchers from the Technical University of Vienna under Prof. Guenter Bloeschl [16], trends in changes in the number and size of floods of different origin in Europe are not straightforward. As an example, chronological series of observations of annual runoff maxima on the Danube River in Vienna have been presented (Fig. 10).

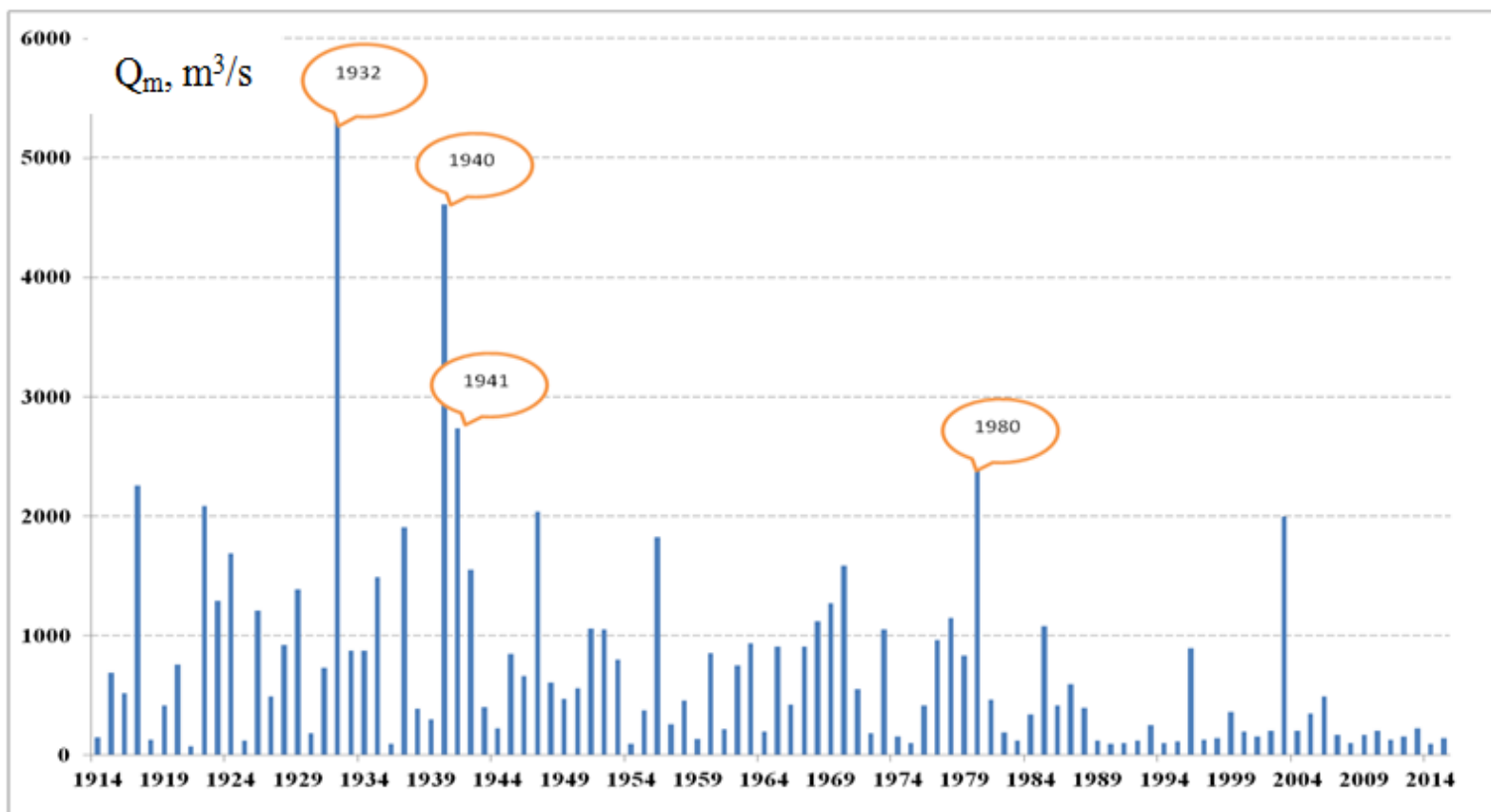

Fig. 2. Time series of spring flood water discharges at the river Desna in Chernigiv 


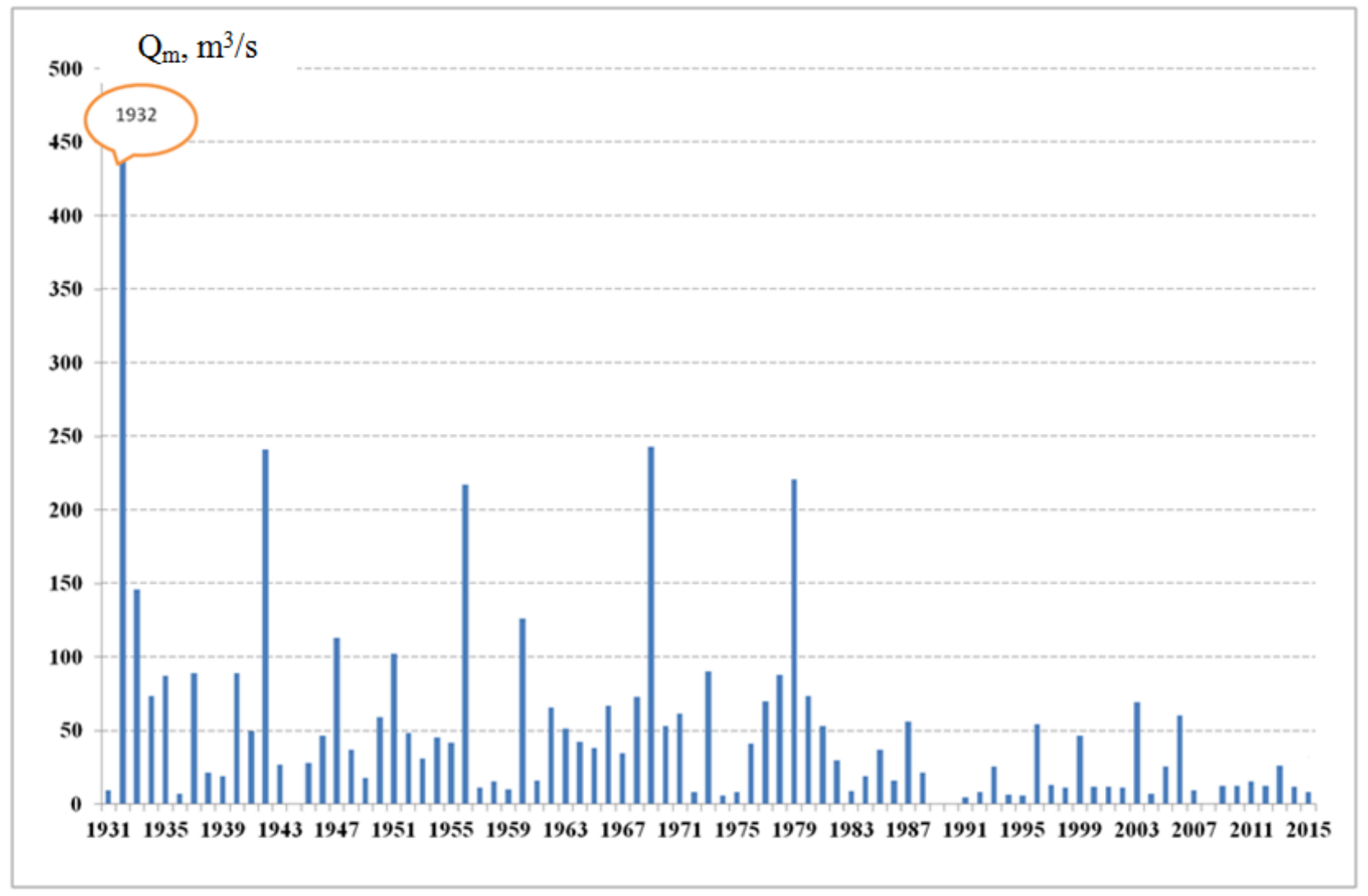

Fig. 3. Time series of spring flood water discharges at the river Southern Bug in urban settlement Oleksandrivka

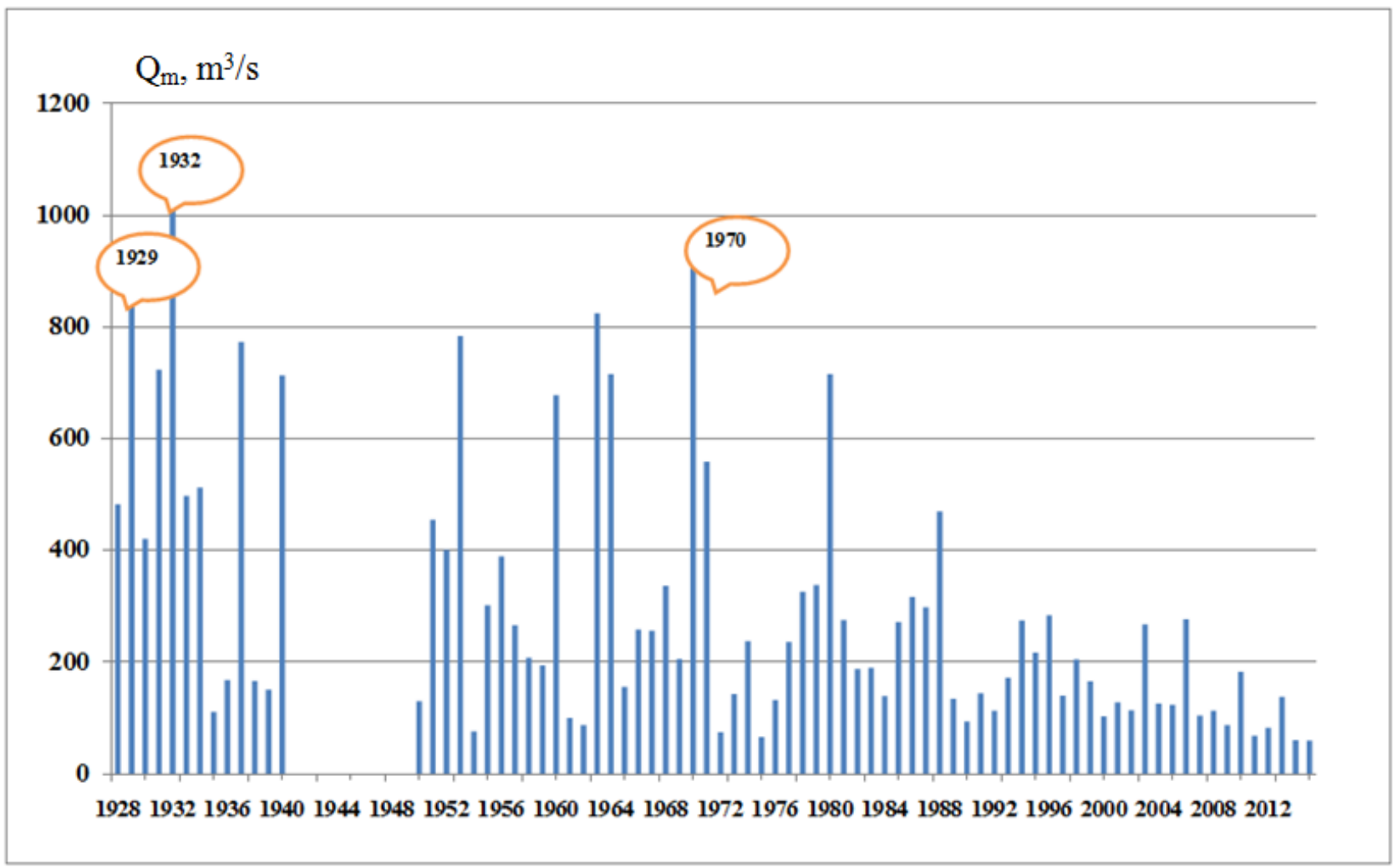

Fig. 4. Time series of spring flood water discharges at the river Smotrych in the village Tsybulivka 


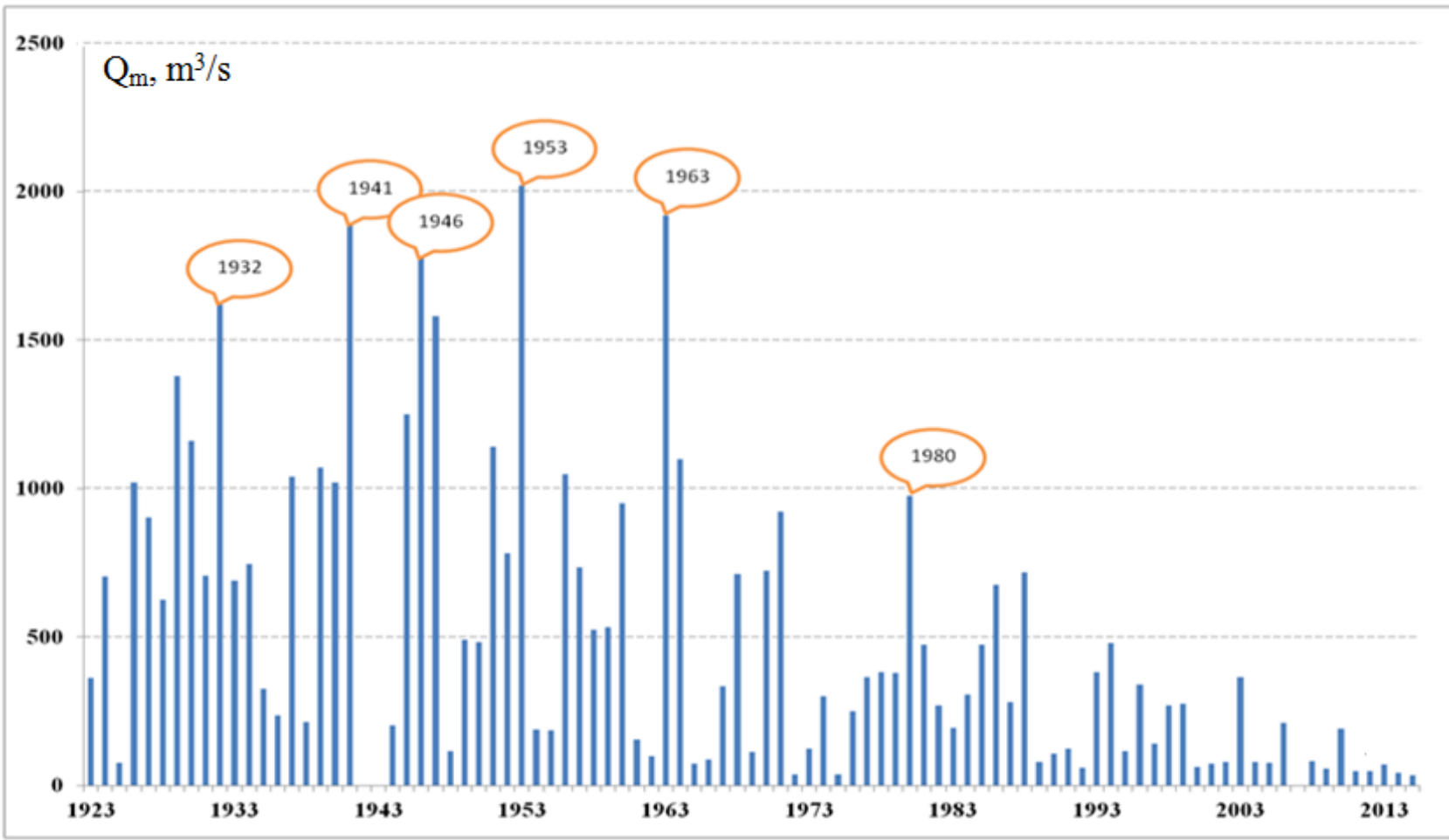

Fig. 5. Time series of spring flood water discharges at the river Psel in the village Zapsillia

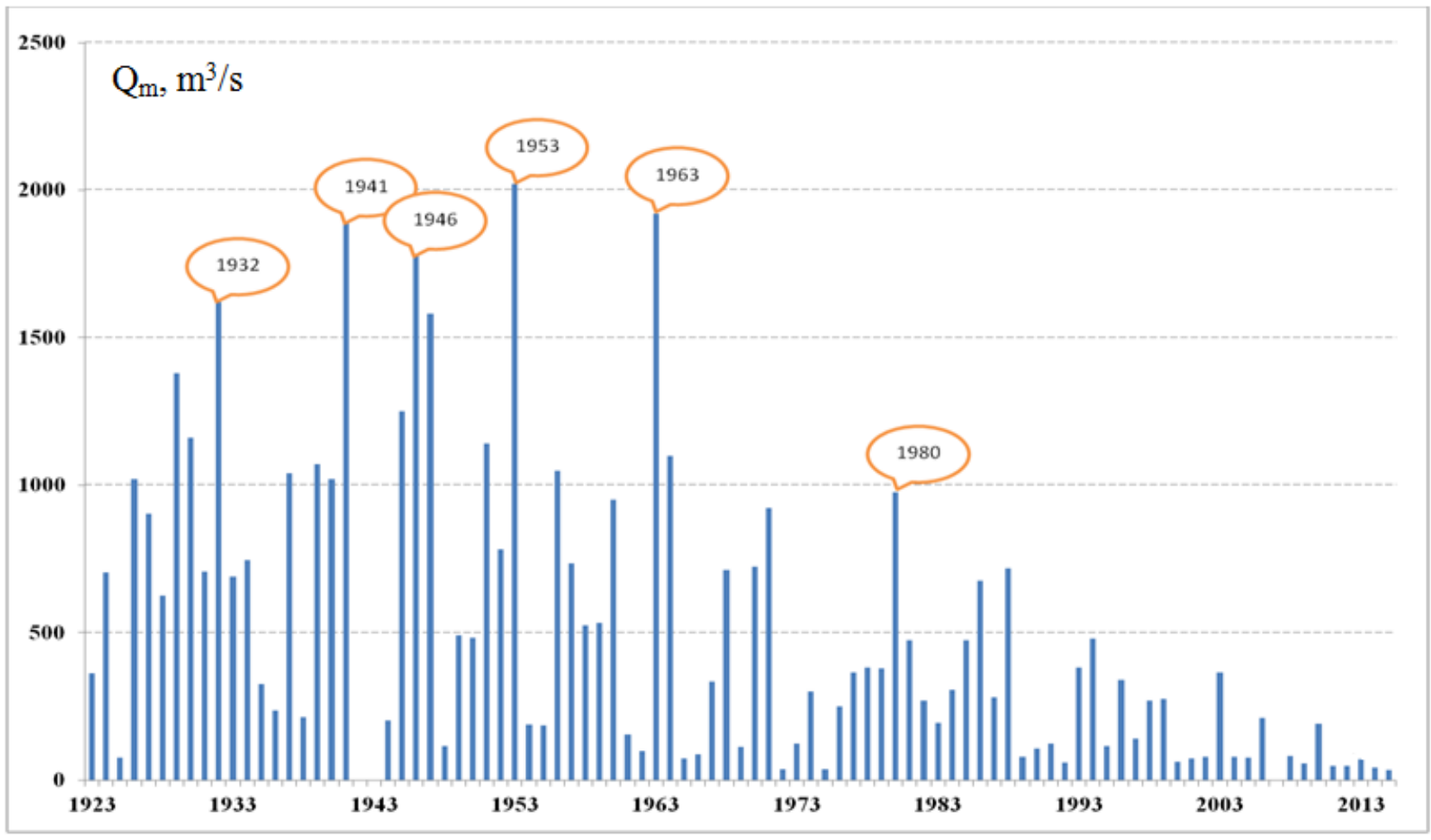

Fig. 6. Time series water discharges of spring flood at the river Siversky Donets - st. Zmiyiv 


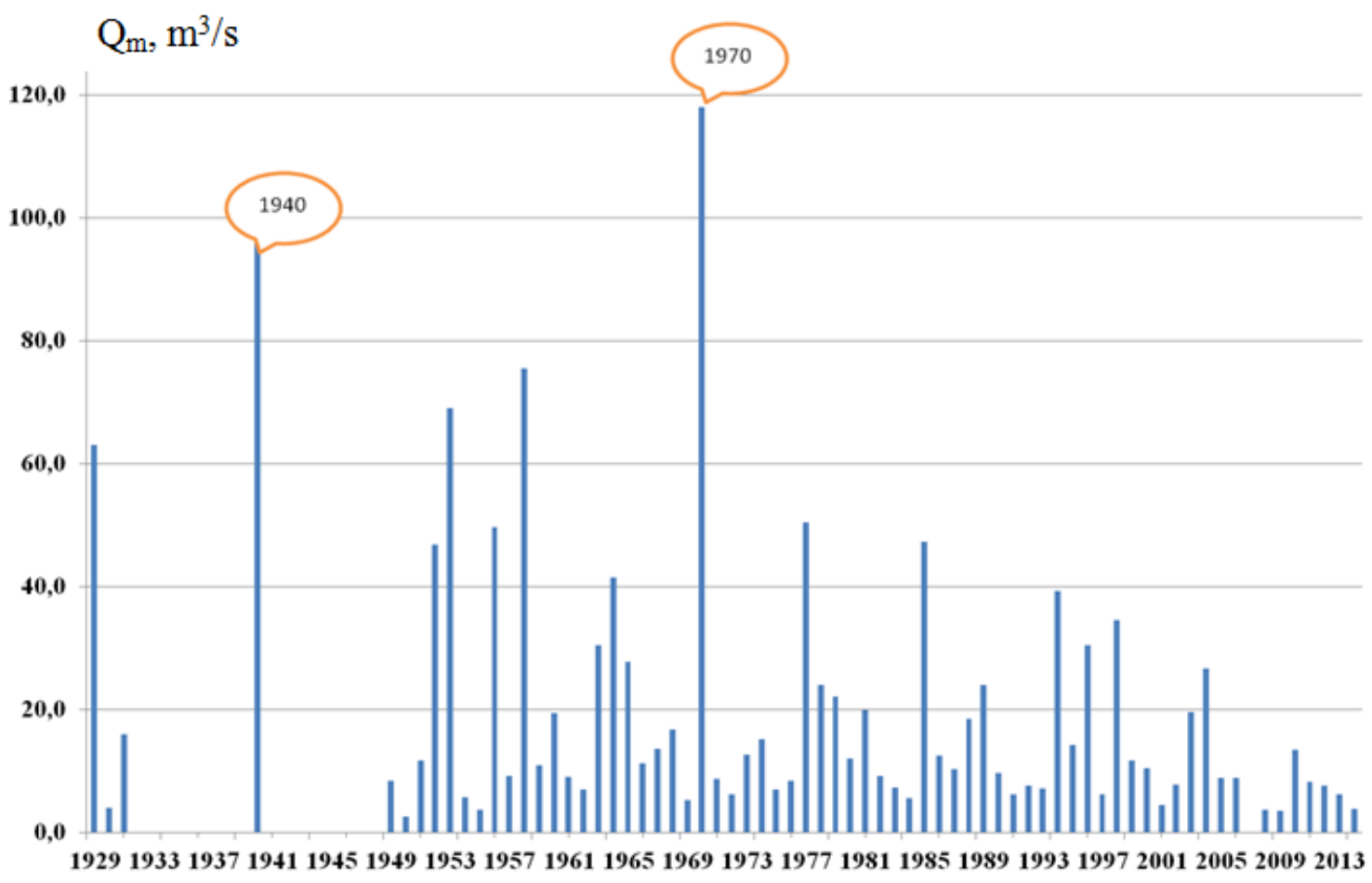

Fig. 7. Time series of spring flood water discharges at the river Krynka in the village Novoselivka

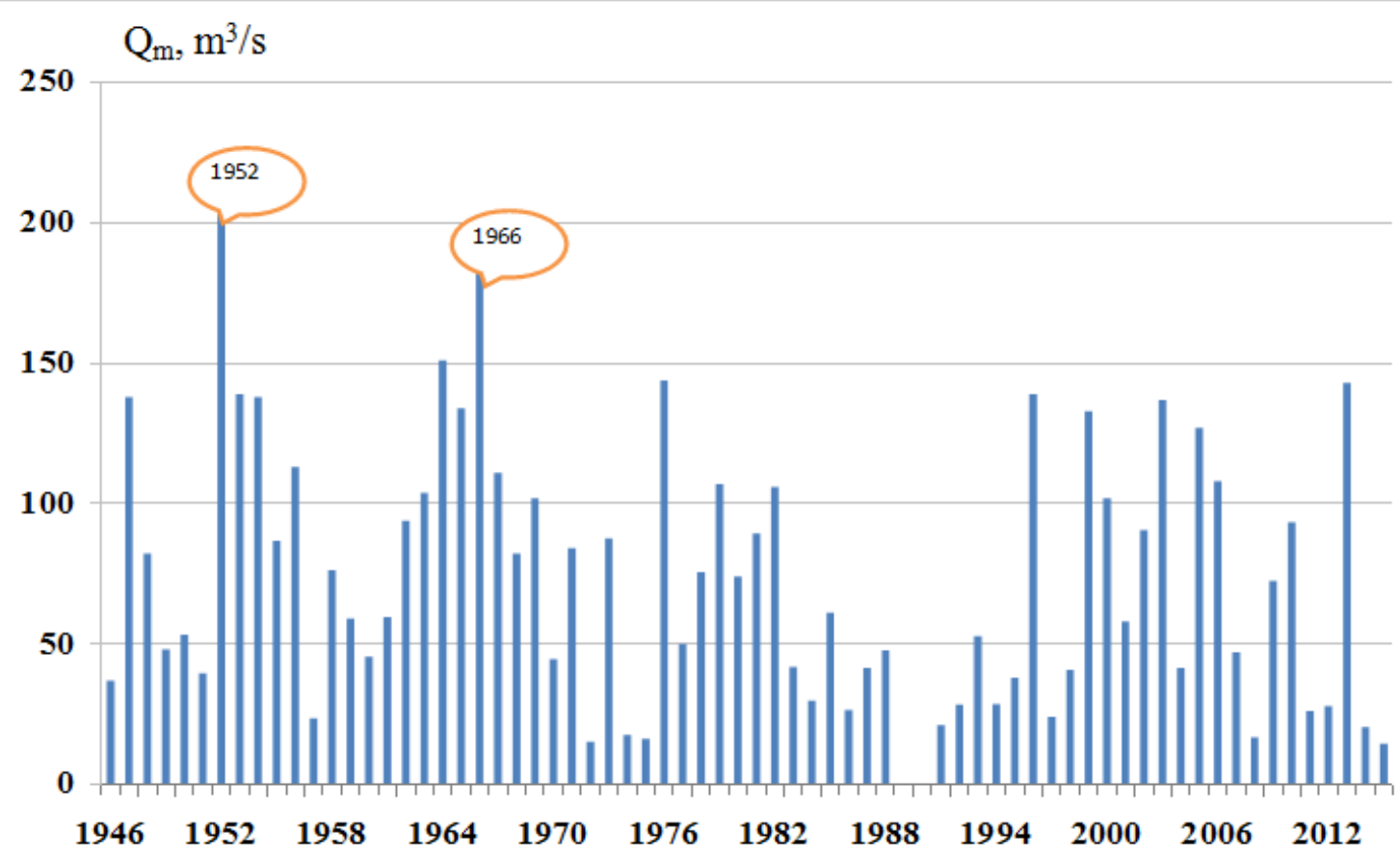

Fig. 8. Time series of spring flood water discharges at the river Western Bug in Kamianka-Buzka 


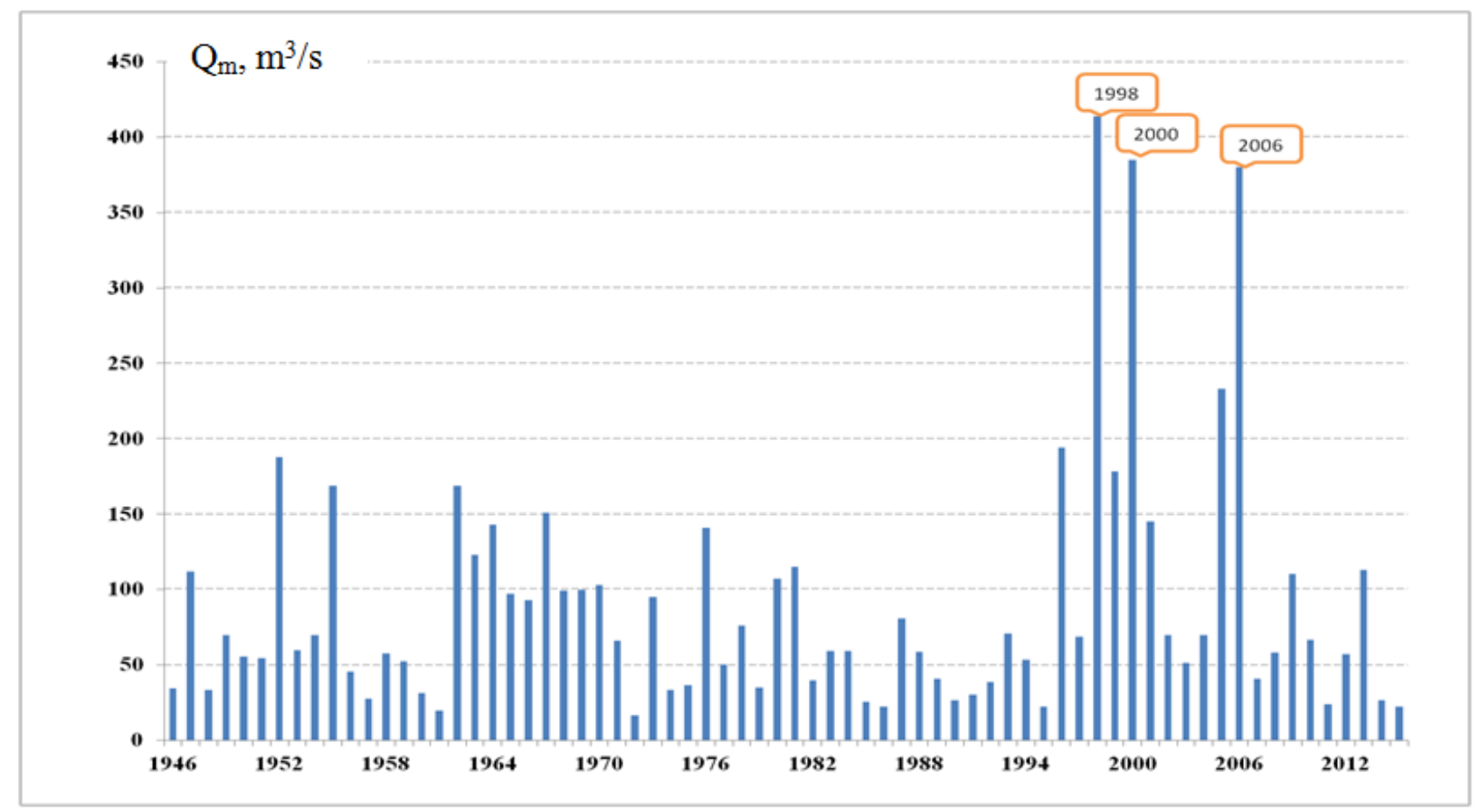

Fig. 9. Time series of spring flood water discharges at the river Dnister in Sambir

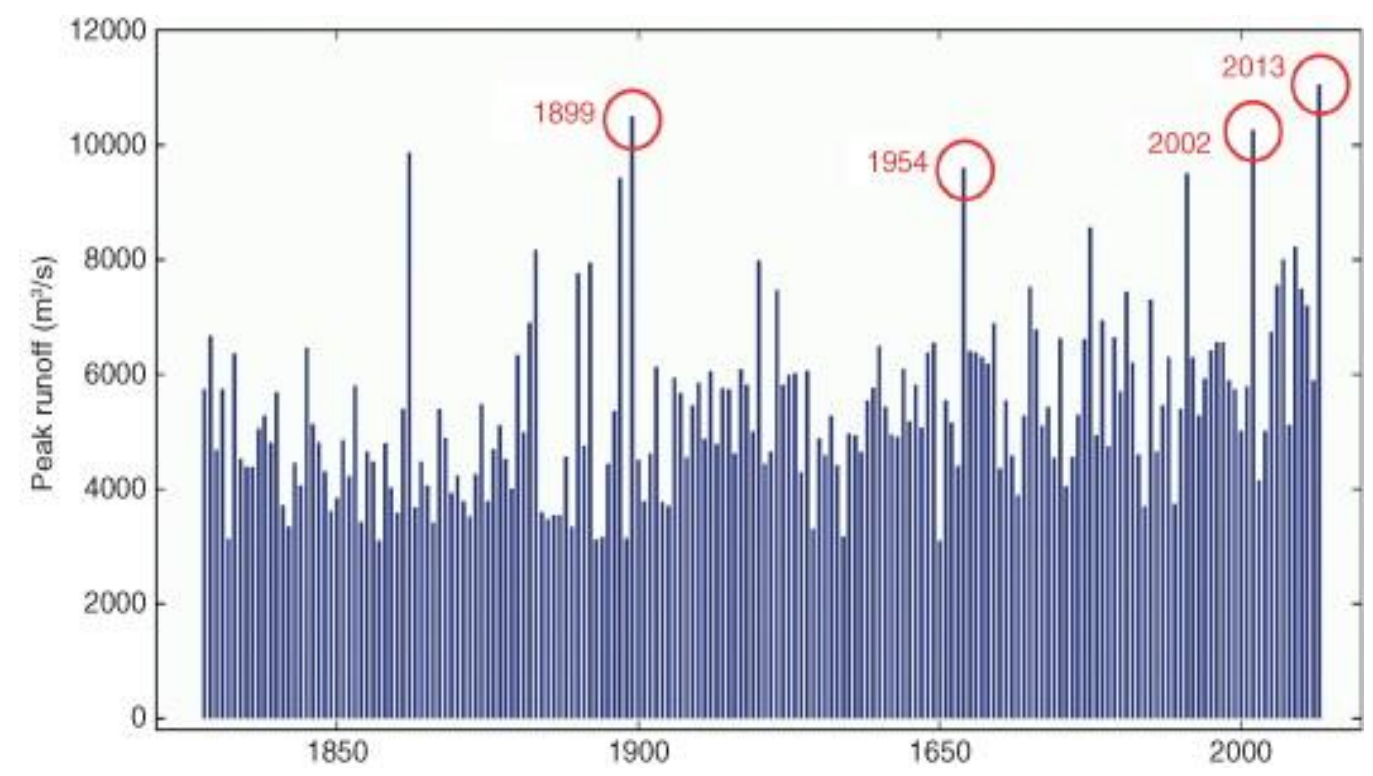

Fig. 10. The maximum annual runoff (the maximum discharge in each year) for the Danube in Vienna between 1828 and 2013 [16]

Considering the chronology of floods in Vienna, Bloeschl notes that there are years with a relatively small peak runoff (which does not actually lead to "flood"), and there are years with a very large runoff, which is definitely qualified as a flood. Four of the largest floods were marked by circles these are floods that occurred in June 2013, August 2002, July 1954, and September 1899. All these floods were formed by heavy precipitation, and the maximum amount of precipitation in a few days exceeded $300 \mathrm{~mm}$. Exceptions were precipitation in September 1899, when their number was much higher (more than $500 \mathrm{~mm}$ ), however, the maximum runoff was not very different from other cases. This is explained by the fact that in September the underlying surface was rather dry due to low summer precipitation. Much of the precipitation, therefore, went into infiltration, and thus actual runoff slightly decreased.

Similar chronological series of observations have been analyzed by numerous researchers for the rivers of Europe to understand whether there are any changes in the magnitude and frequency of floods during the last decades [17-21]. 
To verify the existence of the trend, linear regression has been used, and it has also been assessed whether the trend is statistically significant. In general, these studies for the past decade have demonstrated great attention to the chronology of floods on the rivers in the world, but the data suggests their large spatial heterogeneity. Naturally, this heterogeneity is due primarily to local processes that affect the scale of the flood. But there are also interesting large-scale trends that have been identified as a result of analysis [19]. In particular, on the Iberian Peninsula and in North-Eastern Europe there is a tendency of reduction of flood (due to earlier snow melt period) and in Western Europe there is a tendency of increase (due to increased precipitation). However, the authors of the study [19] note that the analysis results are invariably dependent on the period of observation of a series of floods, and it is not the same for all studied regions, hence the resulting trends require further correction. It should be considered that the territory of Ukraine, as well as European Russia, have not been included in the study, so the trends during the maximum runoff in these areas have not been analyzed.
In 2015-2016, Prof. G. Bloeschl and Dr. J.Hall initiated a new large-scale study in which 35 scientists from most European countries participated, including Ukraine, which was represented by L.Gorbachova, a representative of UkrHMI and one of the authors of this article - V.Ovcharuk. The task of the study was to collect and analyze data of maximal runoff at European Rivers in the period from 1960 to 2010. Information was collected on almost 5000 hydrological stations, including 261 stations in Ukraine. As a result of the analysis of the time series of annual maxima and the dates of their observation on the presence of particular rends, the areas of homogeneous trends have been identified (Fig. 11) [22].

The authors [22] have identified 4 regions with the same tendency of trends and peculiarities of the formation of maximum discharge: 1 - North-Eastern Europe: early snow melt; 2 - the North Sea region: late winter storms; 3 - Western Europe along the Atlantic coast: earlier periods of the onset of maximum soil humidity; 4 - parts of the Mediterranean coast: a stronger influence of the Atlantic in the winter.

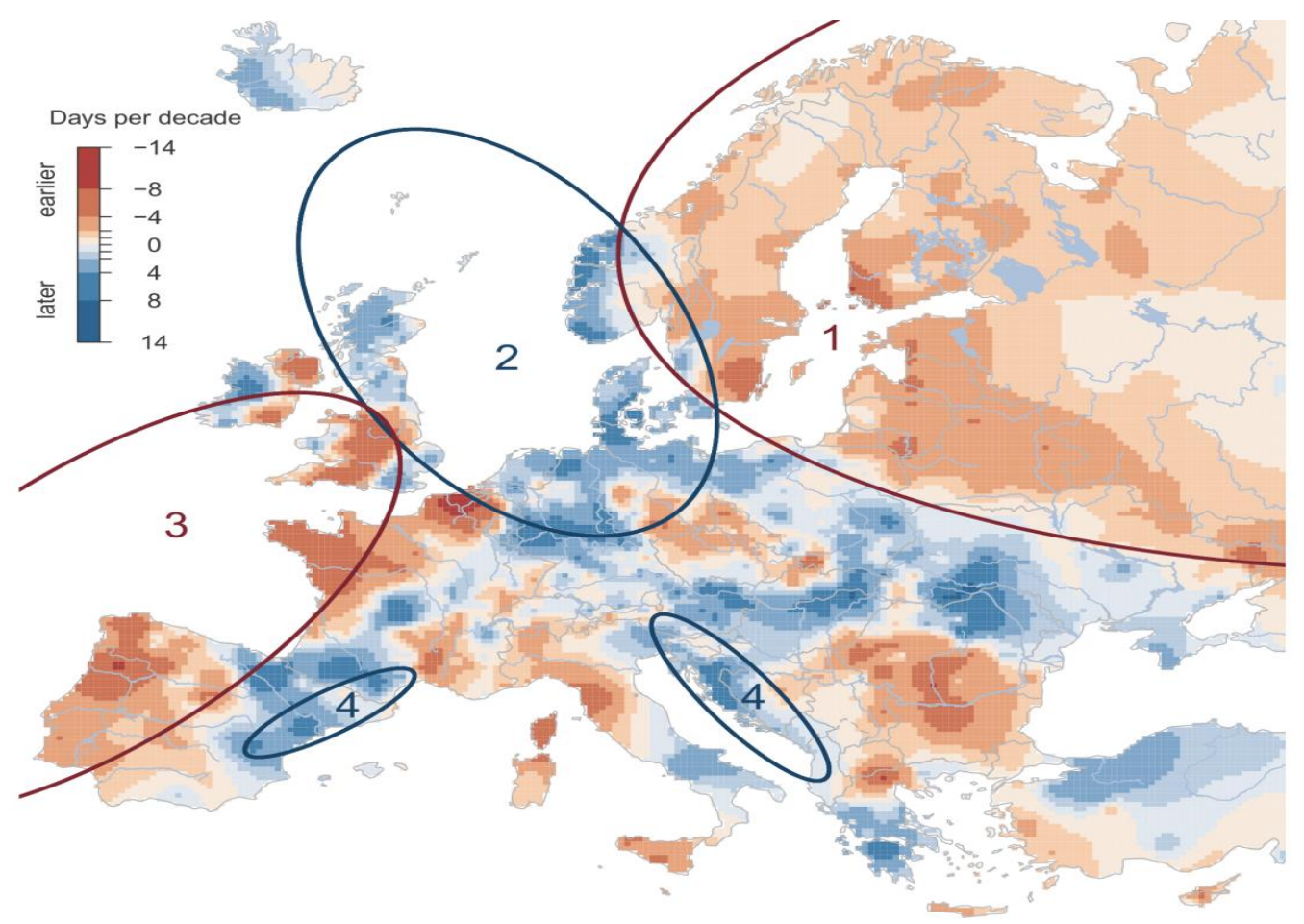

Fig. 11. The observed time trends of maximum river runoff in Europe (1960-2010) [22]

Conclusions. The analysis of historical data, literature sources and available time series of observations for the maximum runoff of rivers show that the greatest risk among natural hazards in Ukraine is floods of different origin.

In the period of regional and global climate change, the territory of Ukraine is not homogeneous with the trends of annual runoff maxima: on the left bank of the Dnieper and in the Siverskyi Donets basin, there is a tendency towards earlier periods of snow melting and occurrence of spring floods, while in the rest of the territory, on the other hand, there is a tendency to increase the incidence of winter floods instead of spring floods.

Nevertheless, in the plain area of Ukraine annual maxima are still observed in the spring, and for 
the territory of the Ukrainian Carpathians the maxima are indicative as a result of floods of the warm period of the year.

Potential danger that occurs during the floods with rare probability of relative height is a reason for the continuous study of these natural phenomena and it necessitates the improvement of methods for their calculation in conditions of unstable climate.

\section{Jimepamypa}

1. Centre for Research on the Epidemiology of Disasters Internationally Reported Losses 1990-2014 EMDAT [Електронний ресурс] / Режим достуny :http://www.preventionweb.net/countries/ukr/data/.

2. The OFDA/CRED - International Disaster Database Université catholique de Louvain Brussels [Електронний ресурс] / Режим достуny : http://www.emdat.be.

3. Making Development Sustainable: The Future Disaster Risk Management. Global Assessment Report on Disaster Risk Reduction. Geneva, Switzerland: United Nations Office for Disaster Risk Reduction (UNISDR) [Електронний pecypc] / Режим достуny : https://archive-ouverte.unige.ch/unige:78299.

4. Source Index for Risk Management 2017 (INFORM 2017) - Inter-Agency Standing Committee Task Team for Preparedness and Resilience and the European Commission [Електронний ресурс] / Режим доступу: http://www.inform-index.org

5. Гопченко, Є.Д. Гідрологічні розрахунки: підручник / Є.Д. Гопченко, Н.С. Лобода, В.А. Овчарук. - Одеса: ТЕС, 2014. $-484 c$.

6. Соколов, А.А. Гидрография СССР / А.А. Соколов. - Л.:Гидрометеоиздат, 1964. - 355 с.

7. Нежиховский, Р.А. Русловая сеть бассейна и процесс формирования стока воды / Р.А. Нежсиховский. - Л.: Гидрометеоиздат, 1971. $-473 \mathrm{c}$.

8. Борисенков, Е.П., Экстремальные природные явления в русских летописях XI-XVII веков / Е.П. Борисенков, В.М. Пасеикий. - Л.: Гидрометеоиздат, 1983. - 240 c.

9. Flooding and sustainable development. - WMO Bulletin. - 2006. - Vol. 55(3). -228 p.

10. Екстремальні гідрологічні явища: паводки і посухи на території гірських регіонів України: колективна монографія /за ред. Є.Д. Гопченка та ін. -Одеса: ТЕС, 2018. - 325 с.

11.Природні катаклізми ХX століття в Украӥні [Електронний ресурс] / Режим доступу: https://day.kyiv.ua/uk/article/cuspilstvo/prirodni-kataklizmi-hh-stolittya-v-ukrayini.

12. Гопченко, Є.Д. Дослідження впливу сучасних змін клімату на характеристики максимального стоку весняного водопілля на річках Полісся / С.Д. Гопченко, В.А. Овчарук, Ж.Р. Шакірзанова // Гідрологія, гідрохімія $і$ гідроекологія. - 2010. - T.3(20). - С. 50-59.

13. Гопченко, С.Д. Зміни гідрометеорологічних характеристик весняного водопілля на рівнинних річках України / С.Д. Гопченко, В.А. Овчарук, Ж.Р. Шакірзанова // Украӥнський гідрометеорологічний журнал. -2012. -№ 10. - C. 133-142.

14. Шакірзанова, Ж.Р. Просторові закономірності у розподілі шарів стоку весняного водопілля рівнинних річок України / Ж.Р. Шакірзанова // Географія та туризм. - 2014. - Вип. 31. - С. 170-178.

15. Гіррологічний режим річок Украӥни у 2010-2013 рр. та його прогнозування. [Електронний ресурс] / Режим docmyny: http://meteo.gov.ua/files/content/docs/Jitomir/4.pdf.

16. Blöschl, Günter Increasing river floods: fiction or reality? / Günter Blöschl, Ladislav Gaál, Julia Hall, Andrea Kiss, Jürgen Komma, Thomas Nester, Juraj Parajka, Rui A. P. Perdigão, Lenka Plavcová, Magdalena Rogger, José Luis Salinas, Alberto Viglione// WIRES Water. - 2015. - Vol. 2. - P. 329-344. https://doi.org/10.1002/wat2.1079.

17. Hall, J. Understanding flood regime changes in Europe: a state of the art assessment / J. Hall, B. Arheimer, M. Borga, R. Brázdil, P. Claps, A. Kiss, T.R. Kjeldsen, J. Kriaučiūnienè, Z.W. Kundzewicz, M. Lang // Hydrol Earth Syst Sci. - 2014. - Vol. 18. - P. 2735-2772. https://doi.org/10.5194/hess-18-2735-2014.

18. Changes in Flood Risk in Europe: / ed. Kundzewicz Z.W. - Wallingford: IAHS Press, 2012. - $516+$ xvi pp.

19. Blöschl, G. The June 2013 flood—analysis and implications for flood risk management / G. Blöschl, T. Nester, J. Komma, J. Parajka, R.A.P. Perdigão // Z Österreich Ingen-\&-Architekten .- 2013. - No 158. - P. 141-152.

20. Sraj, M. The influence of non-stationarity in extreme hydrological events on flood frequency estimation / M. Sraj, A. Viglione, J. Parajka, G. Blöschl // J. Hydrol. Hydromech. - 2016. - Vol. 64. - P. 426-437.

21. Maskey, S. Flood risk in the changing climate / S. Maskey // Journal of Flood Risk Management. - 2018. - P. 109110. https://doi.org/10.1111/jfr3.12458.

22. Blöschl, G. Changing climate shifts timing of European floods / G. Blöschl et al // Science. - 2017/ - Vol. 357, Issue 6351 - P. 588-590. https://doi.org/10.1126/science.aan2506. 
UDC 556.16

Valeriya Anatolievna Ovcharuk,

Doctor of Sciences (Geography), Associate Professor,

Director of the Hydrometeorological Institute of Odessa State Environmental University,

15 Lvivska Str., 65016, Odessa, Ukraine,

e-mail: valeriya.ovcharuk@gmail.com, https://orcid.org/0000-0003-1638-841X;

Oleg Miloslavovich Prokofiev,

$\mathrm{PhD}$ (Geography), Associate Professor,

Department of Meteorology and Climatology, Odessa State Environmental University, e-mail: leggg0707@gmail.com, https://orcid.org/0000-0002-5669-0181;

Olena Ivanivna Todorova,

$\mathrm{PhD}$ (Geography), Senior Lecturer,

Department of Land Hydrology, Odessa State Environmental University,

e-mail: lenochka.todorova1989@gmail.com, https://orcid.org/0000-0001-8937-7952;

Natalia Sergiyvna Kichuk,

$\mathrm{PhD}$ (Geography), Associate Professor,

Department of Land Hydrology, Odessa State Environmental University, e-mail: kichuknatali@ukr.net, https://orcid.org/0000-0002-8165-6743

\section{THE STUDY OF THE PERIODICITY OF CATASTROPHIC SPRING FLOODS ON THE TERRITORY OF UKRAINE}

Introduction. In the period of global and regional climate change in almost all the regions of our planet there is an increase in cases of extreme natural phenomena, which definitely include floods of various origin. Over the past decades, according to the Centre for Research on the Epidemiology of Disasters (CRED), in many countries of the world there has been a record high number of natural disasters which affected about 2.7 billion people, that is more than one third of the world's population.

The purpose of article is to analyze historical data and study the current state and trends in the frequency of catastrophic floods.

Methods. To estimate the trends in the chronological series of the maximum runoff of rivers the methods of statistical analysis and spatial generalization have been used.

Results. On the basis of literature sources and taking into account current data, frequency of flooding in the period from 900 to 2010 in the territory of Kyivan Rus and modern Ukraine has been estimated. Analyzing the results obtained, it can be noted that the largest number of floods was observed in the period from 1501 to 1600 years (11 cases), from 1601 to 1700 years (13 cases), and in the modern period from 1901 to 2000 (10 cases); $900-1000$ and 1701-1800 years can be considered as the periods with the smallest number of cases. Since the beginning of the new millennium catastrophic and high floods have been observed in Europe almost every year. In order to estimate the repeatability of catastrophic floods at the rivers in Ukraine, the chronological series of the maximum runoff of spring water have been made up in accordance with the data of hydrological stations, which have the largest and preferably continuous periods of observations from their beginning until 2015 inclusive. The analysis has shown that in Ukraine the spring floods in 1932 and 1970 are classified as catastrophic. The analysis of trends in the chronological series of annual maxima in conditions of climate change showed their heterogeneity across the territory of Ukraine: on the left bank of the Dnieper and in the Siverskyi Donets basin there is a tendency towards earlier periods of snowmelt and the occurrence of the spring floods, and on the other territory, on the contrary, there is a tendency of increase in cases of winter floods instead of the spring high water.

The scientific novelty of the study is determined by the use of observational data up to 2015 inclusive, and its practical significance is determined by the opportunity to use the results when justifying hydrotechnical projects in order to minimize the consequences of catastrophic floods on rivers.

Keywords: flooding, rain and spring floods, maximum runoff, climate change

\section{References}

1. Centre for Research on the Epidemiology of Disasters Internationally Reported Losses 1990-2014 EMDAT. Available at: http://www.preventionweb.net/countries/ukr/data/.

2. The OFDA/CRED - International Disaster Database Université catholique de Louvain Brussels. Available at: http://www.emdat.be. 
3. Making Development Sustainable: The Future Disaster Risk Management. Global Assessment Report on Disaster Risk Reduction. Geneva, Switzerland: United Nations Office for Disaster Risk Reduction (UNISDR). Available at: https://archive-ouverte.unige.ch/unige:78299.

4. Source Index for Risk Management 2017 (INFORM 2017) - Inter-Agency Standing Committee Task Team for Preparedness and Resilience and the European Commission. Available at: http://www.inform-index.org

5. Gopchenko, Ye.D., Loboda, N.S., Ovcharuk, V.A. (2014). Gidrologichni rozraxunky`: pidruchny`k [Hydrological calculations: a textbook]. Odesa, Ukraine: TES, 484.

6. Sokolov, A.A. (1964). Gidrografija SSSR [Hydrography of the USSR]. Leningrad, Russia: Gidrometeoizdat, 355.

7. Nezhihovskij, R.A. (1971). Ruslovaja set' bassejna i process formirovanija stoka vody [Channel network of the basin and the process of formation of water flow]. Leningrad, Russia: Gidrometeoizdat, 473.

8. Borisenkov, E.P., Paseckij, V.M. (1983). Jekstremal'nye prirodnye javlenija v russkih letopisjah XI-XVII vekov [Extreme natural phenomena in the Russian chronicles of the XI-XVII centuries]. Leningrad, Russia: Gidrometeoizdat, 240.

9. Flooding and sustainable development (2006). WMO Bulletin, 5(3), 228.

10. Gopchenko, Ye.D. ed. (2018). Ekstremal`ni gidrologichni yavy`shha: pavodky`i posuxy`na tery`toriyi girs`ky`x regioniv Ukrayiny` kolekty`vna monografiya [Extreme hydrological phenomena: floods and droughts in the mountain regions of Ukraine]. Odesa: TES, 325.

11. Natural cataclysms of the twentieth century in Ukraine. Available at: https://day.kyiv.ua/uk/article/cuspilstvo/ prirodni-kataklizmi-hh-stolittya-v-ukrayini.

12. Gopchenko, Ye.D., Ovcharuk, V.A., Shakirzanova, Zh.R. (2010). Doslidzhennya vply`vu suchasny`x zmin klimatu na xaraktery`sty ky`maksy`mal 'nogo stoku vesnyanogo vodopillya na richkax Polissya [Investigation of the influence of modern climate changes on the characteristics of the maximum runoff of spring water on the rivers of Polissya]. Hydrology, hydrochemistry and hydroecology, 3(20), 50-59.

13. Gopchenko, Ye.D., Ovcharuk, V.A., Shakirzanova, Zh.R. (2012). Zminy`gidrometeorologichny`x xaraktery`sty`k vesnyanogo vodopillya na rivny`nny`x richkax Ukrayiny`[Changes in hydrometeorological characteristics of spring flood on plain rivers of Ukraine]. Ukrainian Hydrometeorological Journal, 10, 133-142.

14. Shakirzanova, Zh.R. (2014). Prostorovi zakonomirnosti u rozpodili shariv stoku vesnyanogo vodopillya rivny`nny`x richok Ukrayiny` [Spatial patterns in the distribution of layers of spring runoff of plain rivers of Ukraine]. Geography and Tourism, 31, 170-178.

15. Hydrological regime of Ukrainian rivers in 2010-2013 and its forecasting. Available at: http://meteo.gov.ualfiles/content/docs /Jitomir/4.pdf.

16. Blöschl, Günter, Gaál, Ladislav, Hall, Julia, Kiss, Andrea, Komma, Jürgen, Nester, Thomas, Parajka, Juraj, Perdigão, Rui A.P., Plavcová, Lenka, Rogger, Magdalena, Salinas, José Luis, Viglione, Alberto (2015). Increasing river floods: fiction or reality?. WIRES Water, 2, 329-344. https://doi.org/10.1002/wat2.1079.

17. Hall, J., Arheimer, B., Borga, M., Brázdil, R., Claps, P., Kiss, A., Kjeldsen, T.R., Kriaučiūnienè, J., Kundzewicz, Z.W., Lang M. (2014). Understanding flood regime changes in Europe: a state of the art assessment. Hydrol Earth Syst Sci, 18, 2735-2772. https://doi.org/10.5194/hess-18-2735-2014.

18. Kundzewicz, Z.W. ed. (2012). Changes in Flood Risk in Europe. Wallingford: IAHS Press, $516+x v i$ pp.

19. Blöschl, G., Nester, T., Komma, J., Parajka, J., Perdigão, R.A.P. (2013). The June 2013 flood-analysis and implications for flood risk management. Z Österreich Ingen-\&-Architekten, 158, 141-152.

20. Sraj, M., Viglione, A., Parajka, J., Blöschl, G. (2016). The influence of non-stationarity in extreme hydrological events on flood frequency estimation. J. Hydrol. Hydromech, 64, 426-437.

21. Maskey, S. (2018). Flood risk in the changing climate. Journal of Flood Risk Management, 109-110. https://doi.org/10.1111/jfr3.12458.

22. Blöschl, G. et al (2017). Changing climate shifts timing of European floods. Science, 357(6351), 588-590. https://doi.org/10.1126/science.aan2506.

Authors Contribution: All authors have contributed equally to this work. 